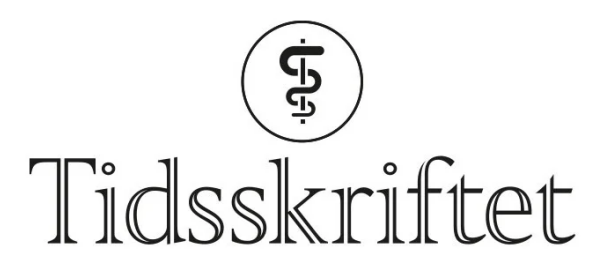

DEN NORSKE LEGEFORENING

\title{
Behov for koordinert tilbud
}

\author{
BREV TIL REDAKTØREN
}

ARNE MOSBERG

Sunnaas sykehus

\section{MARIBETH CAYA RIVELSRUD}

Sunnaas spesialpedagogiske kompetansesenter Sunnaas sykehus

Vi takker Nedrebø og Vaagbø for at de i Tidsskriftet nr. 3/2011 (1) kommenterte vår kronikk (ㅁ). Vi var ikke oppmerksomme på hyperbar oksygenering som metode for behandling av disse pasientene. Dette illustrerer godt vårt hovedpoeng med kronikken, nemlig at det er nødvendig med et faglig tilbud til disse pasientene som er bedre koordinert, både når det gjelder utredning og behandling.

Vi vil i tillegg nevne at vi er blitt gjort oppmerksomme på at man i et forskningsmiljø knyttet til Høgskolen og Universitetet i Bergen prøver ut behandling med lavenergi laser mot stråleindusert oral mukositt. Medlemmene i dysfaginettverket vil bli informert om ovenstående.

\section{LITTERATUR}

1. Nedrebø T, Vaagebø G.. Behandling av svelgevansker etter strålebehandling. Tidsskr Nor Legeforen 2011; 131: 443-4.

2. Mosberg A, Rivelsrud MC. Svelgevansker etter strålebehandling. Tidsskr Nor Legeforen 2010; 130: 2146-2147.

Publisert: 18. mars 2011. Tidsskr Nor Legeforen. DOI: 10.4045/tidsskr.11.0046

(C) Tidsskrift for Den norske legeforening 2023. Lastet ned fra tidsskriftet.no 26. april 2023. 